\title{
PROCLIA- GROUP APHYTISSPP. AS EFFECTIVE PARASITOIDS IN CONTROLING ARMORED SCALE INSECTS IN EGYPT
}

\author{
SHAABAN ABD-RABOU AND NOHA AHMED
}

Plant Protection Research Institute, Agricultural Research Center, Dokki, Giza, Egypt.

(Manuscript received $2^{\text {nd }}$ July 2012)

\begin{abstract}
Aphytis spp. the proclia- group (Hymenoptera : Aphelinidae) are the most important group as a parasitoids of armored scale insects (Hemiptera: Diaspididae). The present work dealt with the host insect, distribution, diagnosis, first literature record, key of the members of Aphytis spp. the proclia- group and the role of this group in controlling armored scale insects. The results indicated that six parasitoids of Aphytis spp. the proclia- group were reared from samples of armored scale insects. These parasitoid species were collected from 9 armored scale insects species and distributed in 16 governorates. A key of Aphytis spp. the procliagroup was also provided as well as literature cited of the first recorded species of these parasitoids. The maximum rate of parasitism for Aphytis spp. the proclia- group ranged between 25.1 to $66.1 \%$. This result indicated that the parasitoids Aphytis spp. the proclia- group were effective in controlling some armored scale insects.
\end{abstract}

\section{INTRODUCTION}

The main injury caused by armored scale ( Hemiptera: Diaspididae) is caused by sucking plant sap. The damage is manifested in reduction of plant vigor. Severely infested plants grow poorly, may drop leaves prematurely, and suffer dieback of twigs and branches. The infested host plant can be so weakened that it dies. Control of these pests by the application of chemical insecticides is a quick and easy step towards the reduction of their population density. However, the use of pesticides is accompanied by many problems, which include the toxic effects on human beings and animals as well as beneficial insects. Pesticides also badly affect soil fauna through their accumulation in the soil. However, the control of armored scale insects in Egypt still relies on the use of insecticides, such as organophosphates or mineral oils, especially in the summer during heavy infestations (Abd-Rabou, 1997a). Rosen and DeBach (1979) treated and recorded 90 world species. Several others have been described since then, bringing the total of known species to about 112 (Hayat, 1983 and Rosen, 1988). In Egypt this genus has 17 species ( Abd-Rabou, 2004). 
The species of genus Aphytis Howard ( Hymenoptera : Aphelinidae) develop exclusively as primary ectoparasitoids of armored scale insects (Homoptera : Diaspididae) and are usually the most abundant and effective natural enemies of thses serious pests. Several species of Aphytis have been successfully employed in biological control against economically important armored scale insects. The abundance of Egyptian Aphytis spp. the proclia- group have attracted many authors (e.g. Moursi \& Mesbah (1985), Hafez et al.,(1987), Hafez (1988), Abd-Rabou (1997 b) and Abd-Rabou \& Hendaway (2000).

The aim of this research paper is to study host insect, distribution, diagnosis, first literature record and the abundance of Aphytis spp. the proclia- group associated with armored scale insects in Egypt. As well as a key of the members of this group.

\section{MATERIALS AND METHODS}

A preliminary survey was conducted during 2010-2011 on different host plant infested by different species of armored scale insects in Egypt to determine the presence of these armored scale insects. In the mean time through this survey the distribution of the parasitoids Aphytis spp. the proclia- group investigated. Another survey conducted during 2010-2011 in 5 governorates to determine the impact of the parasitoids Aphytis spp. the proclia- group on existing in armored scale insects.

Samples of various armored scale insects were collected to study the population dynamics of Aphytis spp. the proclia- group on ten host plants as follow: Citrus sp.: 20 trees, 25 years old, and 2.5m in height located at each of Qalyubiya, Ficus nitida: 10 trees, many years old, and $2 \mathrm{~m}$ in height located at each of Qalyubiya. Oleander sp.: 5 trees, many years old, and $1.5 \mathrm{~m}$ in height located at Behira. Mangifera indica: 10 trees, 25 years old, and $8 \mathrm{~m}$ in height located at Giza. Olea europaea: 10 trees, 20 years old, and $4.5 \mathrm{~m}$ in height located at each of Alexandria and Matruh. The selected plants for the present investigation did not receive any chemical control for several years ago before this study. The samples were collected half monthly from Alexandria, Behira, Giza, Qalyubiya, Matruh Each leaf was stored in a well-ventilated emergency glass tube and monitored daily for the emergence of parasitoids. Two methods were used to count the first and second nymphal instars, non gravid females, and the males (preadult) ( scale stages) of armored scale insects and their parasitoids on the plant leaves as follows:

The first method: Square-inch method: In this method, one square-inch was defined on the underside of each leaf and the armored scale insects and their 
parasitoids were counted and recorded. This technique was used in the following plant species: M. indica, Oleander sp. The second method: Whole leaf area method: In this method, all scales found on the whole area of each leaf were counted and recorded. This method was used in the case of Citrus sp., F. nitida and Olea sp. The parasitism rate was determined by dividing the number of emerging parasitoids by the number of hosts. Figures adopted and modified after Abd-Rabou (2004).

\section{RESULTS AND DISCUSSION}

I. List of Aphytis spp. the proclia- group parasitoids attacking armored scale insects in Egypt:

1. Aphytis diaspidis (Howard)

2. A. hispanicus (Mercet)

3. A.maculicornis (Mercet)

4. A. paramaculicornis De Bach \& Rosen

5. A. philippinensis DeBach \& Rosen

6. A. vandenboschi DeBach \& Rosen

II. Armored scale insects (Hemiptera: Diaspididae) hosts of Aphytis spp. the proclia- group in Egypt

1. Aspidiotus nerii Bouche

2. Chrysomphalus anonidum

3. Chrysomphalus dictyospermii

4. Diaspis echinocacti

5. Hemiberlesia latania

6. Insulaspis pallidula (Green)

7. Lepidosaphes beckii

8. Lepidosaphes ulmi

9. Parlatoria oleae

III. Distribution of Aphytis spp. the proclia- group in Egypt:

Alexandria, Assiut, Beheria, Beni-Suef, El-Minya, Giza, , Fayoum, Kafr ElShikh, Ismailia, Matruh, Minufiya, Qalyubiya, Northern Coast , Sharqiya, Sinai and Suez governorates. 


\section{Key to species of Aphytis spp. the proclia- group in Egypt modified after (Abd-Rabou and Hayat, 2003)}

1. Gaster uniformly fuscous or dusky dorsally, with distinct darker cross-bands on terga. (Pedicel and flagellum rather uniformly fuscous, tip of club usually blackish.)

Aphytis diaspidis (Howard)

-.Gaster not uniformly fuscous or dusky, but paler with short fuscous and strips on sides, and at most with complete cross-bands on terga 1-5 (TI-V) 2

2.First tergite (TI) of gaster with a fuscous cross-band, that on TV obliterated centrally (Pedicel and flagellum uniformly fuscous, apex of club blackish) Aphytis hispanicus (Mercet)

-.TI and TV of gaster with complete fuscous cross-bands .3

3. Antennal club with basal part paler than funicle, apex of club blackish; propodeal crenulae elongate 4

-. Antenna with pedicel, funicle and basal part of club uniformly colored, strongly infuscate; apex of club blackish; propodeal crenulae rounded .5

4.Club usually more than $3 x$ as long as broad. Uniparental species Aphytis maculicornis (Mercet)

-.Club usually about $3 \mathrm{x}$ as long as broad. Biparental species Aphytis paramaculicornis DeBach \& Rosen

5. Mid lobe of mesoscutum usually with 10-12 setae; TV of gaster with 3-5 setae in a line between the lateral fuscous strips; TVI with 6-10 setae in a line between spiracles; propodeum not more than $3 x$ as long as metanotum. Uniparental species. Aphytis vandenboschi Rosen \&DeBach

-.Mid lobe of mesoscutum with 15 setae; TV with 2 setae between the lateral fuscous strips; TVI with 4 setae between spiracles; propdeum 3-4 $\mathrm{x}$ as long as metanotum. Biparental species Aphytis philippinensis Rosen \&DeBach

\section{First record literatures of Aphytis spp. the proclia- group in Egyptian fauna}

A. diaspidis and A.maculicornis were recorded for the first time in Egypt by Priesner and Hosny (1940). A. hispanicus, A. paramaculicornis, A. philippinensis and $A$. vandenboschi. were recorded for the first time in Egypt by Abd-Rabou and Hayat (2003). 


\section{Diagnosis of the members of Aphytis spp. the proclia- group in Egypt}

\section{Aphytis diaspidis (Howard) (Figs. A-C)}

Diagnosis: This is biparental and uniparental. Occiput with a fuscous to black bar on each side of foramen, the mouth margin and malar sulcus fuscous. Gaster uniformly fuscous or dusky dorsally, with distinct darker cross-bands on terga. Pedicel and flagellum rather uniformly fuscous, tip of club usually blackish, 7 sensilla. Mesoscutum with 16 setea, crenulae usually wider, more rounded and 6 non overlapping. The relative length of the ovipositor 1.3 times as long as midtibia.

Abundance: The seasonal activity of this parasitoid on $P$. oleae is presented in Fig. 1.The rate of parasitism for $A$. diaspidis on $P$. oleae infesting Olea europaea at Alexandria. Its maximum to be reached 50.2 and $38.4 \%$ with means of 26.5 and $19.7 \%$ over 2010 and 2011, respectively. Dates of maximum activity were May $1^{\text {st }}$, 2010 and May $1^{\text {st }}, 2011$.

Remark: The maximum parasitism rate of $A$. diaspidis on P.oleae on Olea europaea in Northeren Coast was $26.1 \%$ during May, with an average rates $7.9 \%$ (AbdRabou,2001).

\section{Aphytis hispanicus (Mercet) (Figs. D-F)}

Diagnosis: This is palearctic and uniparental species. Occiput with a fuscous to black bar on each side of foramen. Gaster not uniformly fuscous or dusky dorsally, but paler with short fuscous strips on sides, and at most with complete cross-bands on terga 15 (TI-V). First tergite (TI) of gaster with a fuscous cross-band that on TV obliterated centrally. Pedicel and flagellum uniformly fuscous; apex of club blackish, club 6 sensillae; mesoscutum 13 setae; propodeum 0.6 as long as scutellum, 4 times as long as metanotum.Marginal fringe 0.3 as long as width of disk. Basitarsus 1.1 times as long as midtibial, 2.4 times as long as sheath and 0.7 as long as ovipositor.

Abundance: The seasonal activity of this parasitoid on $C$. dictyospermii is presented in Fig. 2. Maximum activity for parasitoid wa recorded in the middle of June in the first year (2010). Hile it was appeared one month earlier in the second year of inspection for $A$. hispanicus on $C$. dictyospermii infesting F. nitida at Qalyubiya. Maximum rate of parasitism reached 41.2 and $39.1 \%$ with means of 17.7 and $18.1 \%$ over 2010 and 2011, respectively. Dates of maximum activity were June 15, 2010 and May 15, 2011.

Remark : The maximum parasitism rates of $A$. hispanicus on I.pallidula on M. indica in Ismailia was 9.4\% during Oct., with an average rates 3.7\% (Abd-Rabou, 2006).

\section{Aphytis maculicornis (Mercet) (Fig. G)}

Diagnosis: This is palearctic and uniparental species. Occiput with a fuscous to black bar on each side of foramen, the mouth margin and malar sulcus fuscous. Antennal club with basal part paler than funicle, apex blackish, usually more than 3 times as 
long as broad; pedicel usually twice as long as wide.Mesoscutum 8-10 setae; delta are

sometime not clearly separated from row of setae; propodeal crenulae elongate.

Abundance: The seasonal activity of this parasitoid on L. Ulmi is presented in Fig. 3 . The parasitoids were observed for A. maculicornis on L. ulmi infesting M. indica at Giza. The rate of parasitism showed the same pattern in the two years of study. Maximum activity for the rate of parasitism were coincided for two years which occurred in the middle of May recording 51.17 and $41.2 \%$.

Remark: This parasitoid recorded only by Priesner and Hosny (1940).

\section{Aphytis paramaculicornis De Bach \& Rosen (Figs. H-J)}

Diagnosis: This is biparental and solitary parasitoid species. Occiput with a fuscous to black bar on each side of foramen, the mouth margin and malar sulcus fuscous. Pedicel 1.8 times as long as wide, antennal club with basal part paler than funicle, apex of club usually about 3 times as long as beoad; delta 130 setae in 10 rows and mesoscutum 14 setae.

Abundance: The parasitism was observed for $A$. paramaculicornis on $P$. oleae infesting $O$. europaea at Matruh. Maximum rate of parasitism reached 66.1 and $29.1 \%$ with means of 23.5 and $15.4 \%$ over 2010 and 2011, respectively. Maximum activity was occurred in the middle April in the first year while it appeared in the first of July in the second year of inspection. The seasonal activity of this parasitoid on $P$. oleae is presented in Fig. 4.

Remark: About 57000 individuals of A.paramaculicornis was released on olive trees infested by $P$.oleae in Northeren Coast, parasitism rates increased from $7 \%$ to $16 \%$ (Abd-Rabou, 2001).

\section{Aphytis philippinensis DeBach \& Rosen (Figs. K-M)}

Diagnosis: This is biparental and southeast Asian species .Occiput with a fuscous to black bar on each side of foramen, the mouth margin of fuscous. Mesoscutum with 15 setae; TV with 2 setae between the lateral fuscous strips, TVI with 4 setae between spiracles; propodeum 3-4 times as long as metanotum and non overlapping 10 crenulae. Ovipositor 1.7 times as long as midtibia, 4.3 times as long as sheath and sheath 0.4 as long as midtibia.

Abundance: The parasitism was observed for $A$. philippinensis on $C$. anonidum infesting Citrus sp. at Qalyubiya. Maximum rate of parasitism reached 30.1 and $25.1 \%$ with means of 10.8 and $8.2 \%$ during 2010 and 2011, respectively. The maximum activity was coincided in the two years which occurred in the middle of June 15 . The seasonal activity of this parasitoid on $C$. anonidum is presented in Fig. 5 . 
Remark: The maximum parasitism rates of $A$. philippinensis on $C$. aonidum on Oleander sp. in Qalyubiya was $1.1 \%$ during Nov., with an average rates of $0.1 \%$. (Abd-Rabou, 2006).

\section{Aphytis vandenboschi (DeBach \& Rosen ) (Figs. N-P)}

Diagnosis: This is uniparental species. Occiput with a fuscous to black bar on each side of foramen, the mouth margin of fuscous. Mesocutum usually with 3-5 setae in a line between the lateral fuscous strips; TVI with 6-10 setae in a line between spiracles; propodeum not more than 3 times as long as metanotum; non overlapping 9 crenulae. Ovipositor 1.5 times as long as midtibia, 3.2 times as long as sheath and sheath 0.4 as long as midtibia.

Abundance: The parasitism was observed for $A$. vandenboschi on $A$. nerii infesting Oleander sp.at Behira. Maximum rate of parasitism reached 39.4 and $31.4 \%$ with means of 18.2 and $12.4 \%$ during 2010 and 2011, respectively. Dates of maximum activity were June 15, 2010 and August 15, 2011. The seasonal activity of this parasitoid on $A$. nerii is presented in Fig. 6 .

Remark: This parasitoid was collected by Abd-Rabou (2006) in a few numbers. 


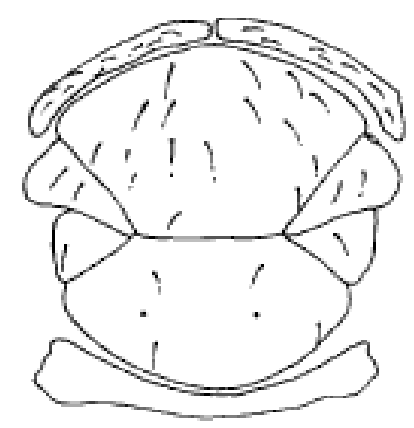

A

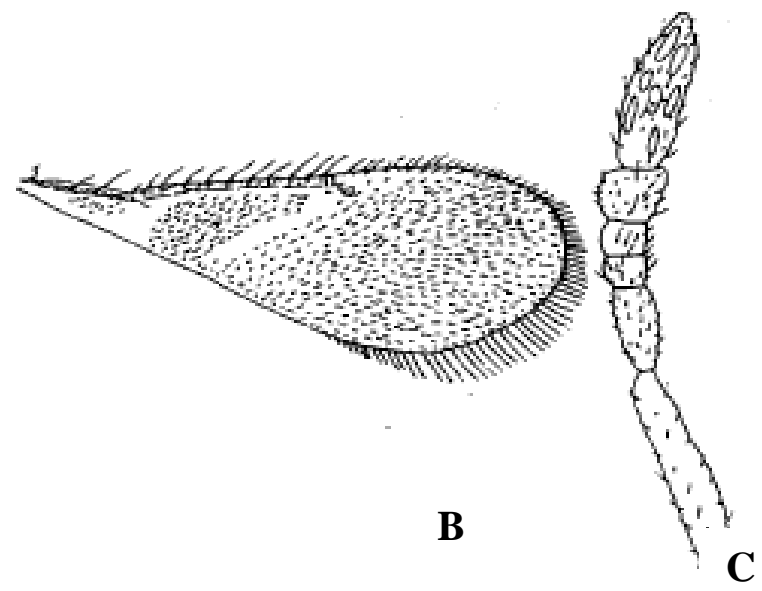

Figs. (A-C). Aphytis diaspidis (Howard). (A) Mesoscutum and scutellum, (B) Forewing , (C) Female antenna.

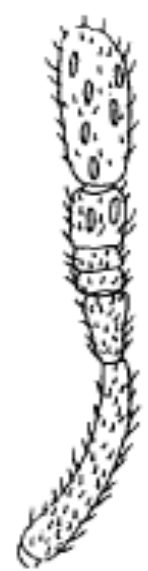

D

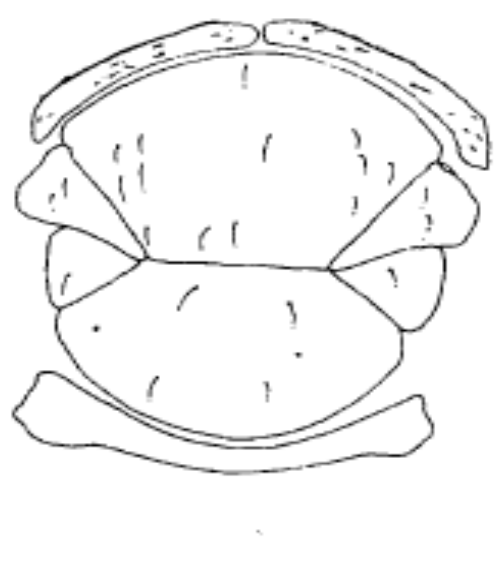

$\mathbf{E}$

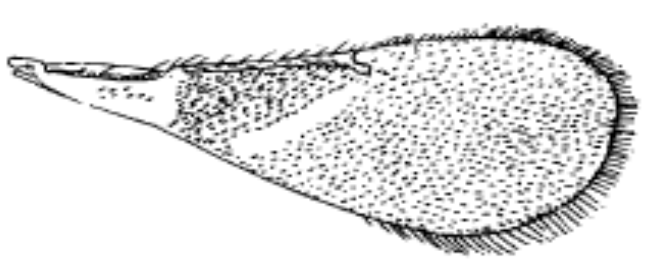

$\mathbf{F}$

Figs. (D-F). Aphytis hispanicus (Mercet). (D) Female antenna. (E) Mesoscutum and scutellum, (F) Forewing . 
Fig.(G). Female antenna of Aphytis maculicornis (Mercet)

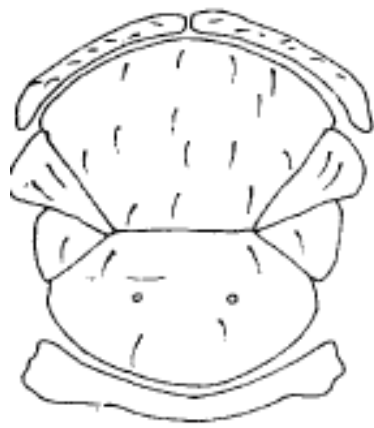

$\mathbf{H}$

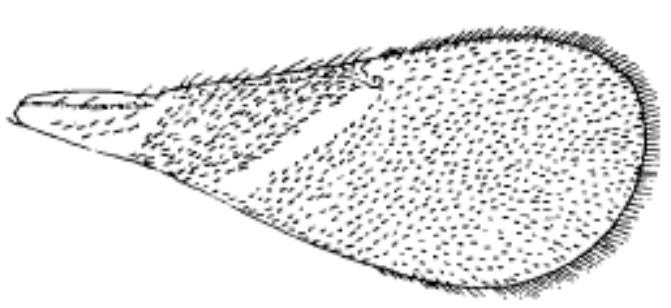

I

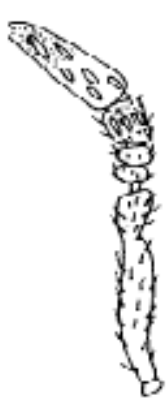

$\mathbf{J}$

Figs (H-J). Aphytis paramaculicornis DeBach \& Rosen. (H) Mesoscutum and scutellum, (I) Forewing , (J) Female antenna. 


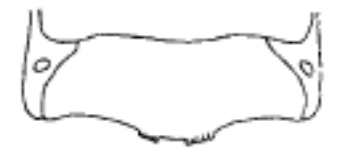

$\mathbf{K}$

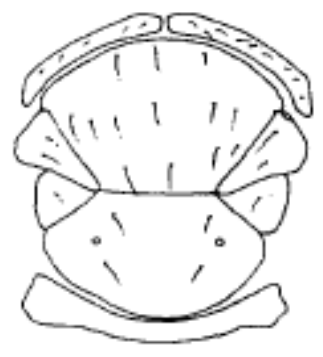

$\mathbf{L}$

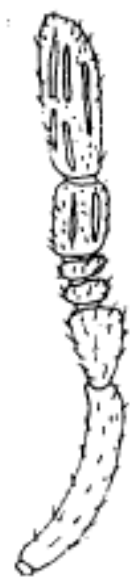

M

Figs (K-M). Aphytis philippinensis Rosen \&DeBach. (K) Propodeum, (L) Mesoscutum and scutellum , (M) Female antenna.

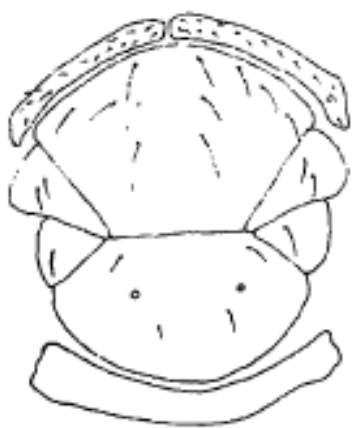

$\mathbf{N}$

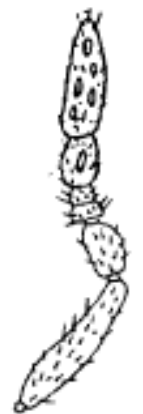

$\mathbf{O}$

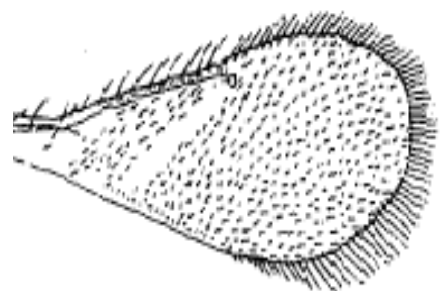

$\mathbf{P}$

Figs (N-P). Aphytis vandenboschi Rosen \&DeBach. (N) Mesoscutum and scutellum, (O) Forewing , (P) Female antenna. 


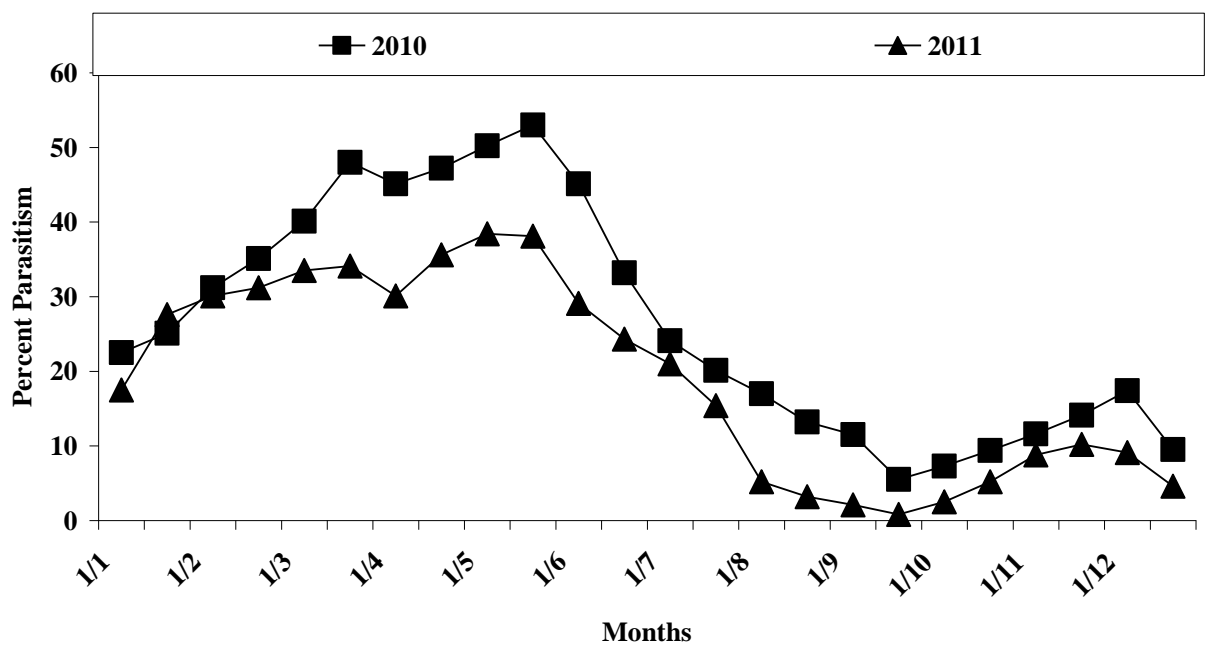

Fig. (1): Percent parasitism by Aphytis diaspidis associated with Parlatoria oleae infesting Olea europaea at Alexandria

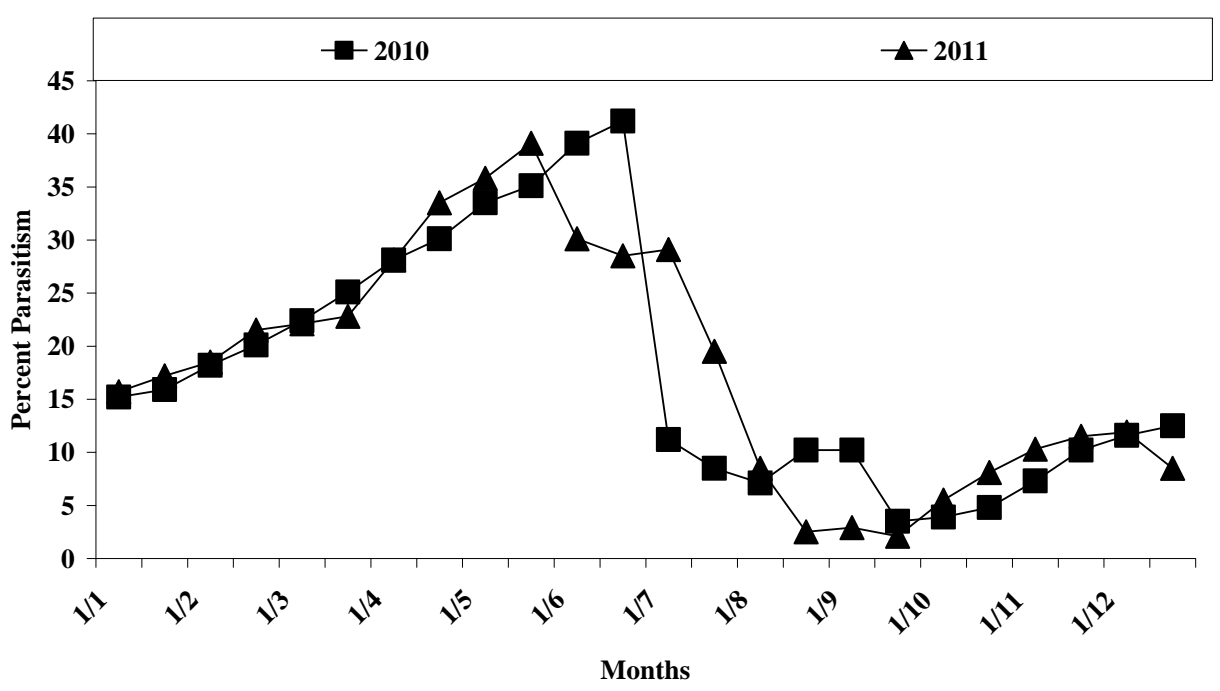

Fig. (2): Percent parasitism by Aphytis hispanicus associated with Chrysomphalus dictyospermii infesting Ficus nitida at Qalyubiya 


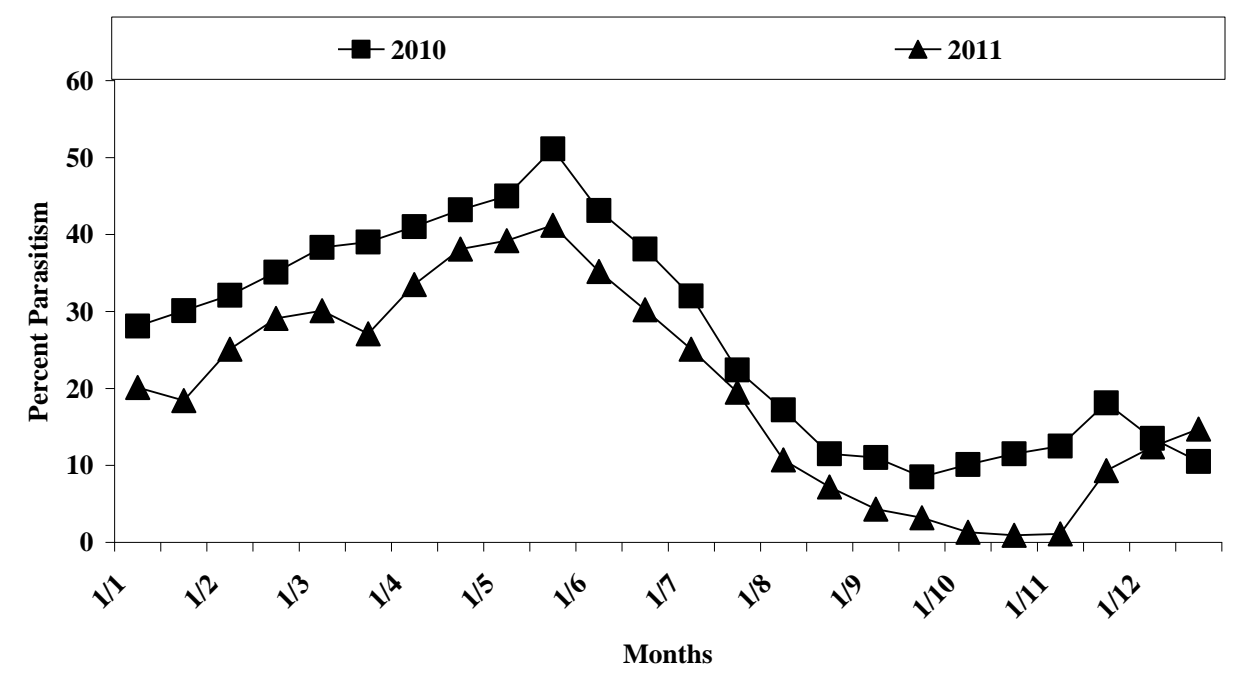

Fig. (3): Percent parasitism by Aphytis maculicornis associated with Lepidosaphes ulmi infesting Mangifera indica at Giza.

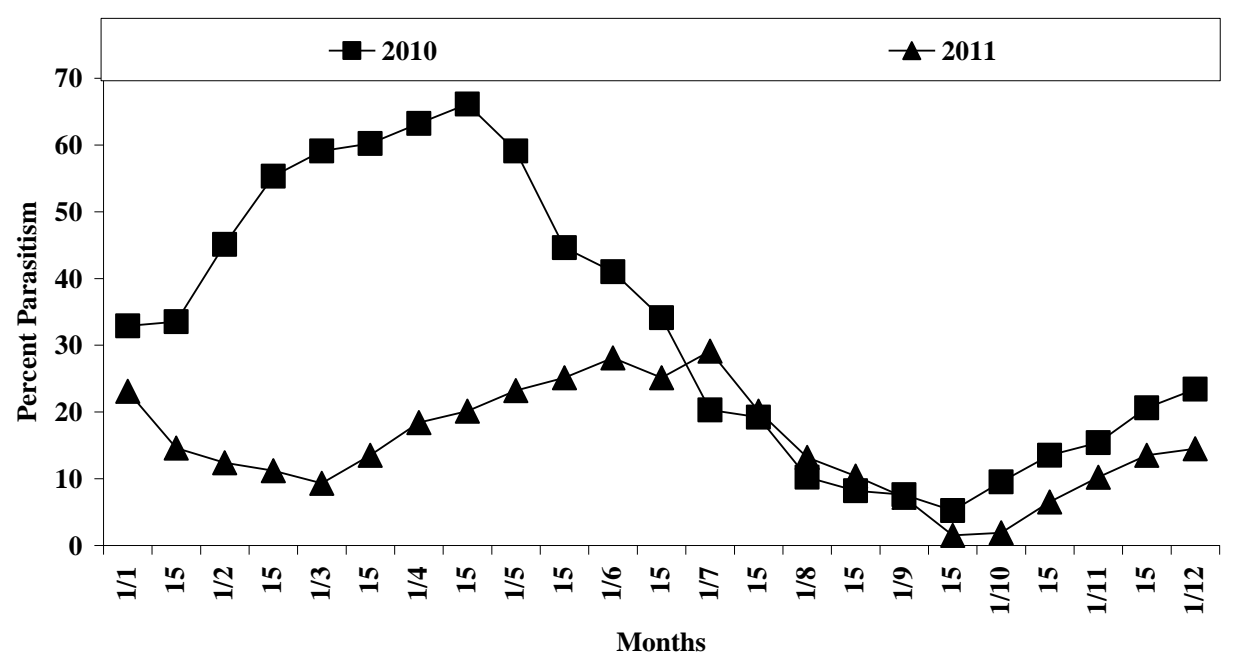

Fig. (4): Percent parasitism by Aphytis paramaculicornis associated with Parlatoria oleae infesting Olea europaea at Matruh. 


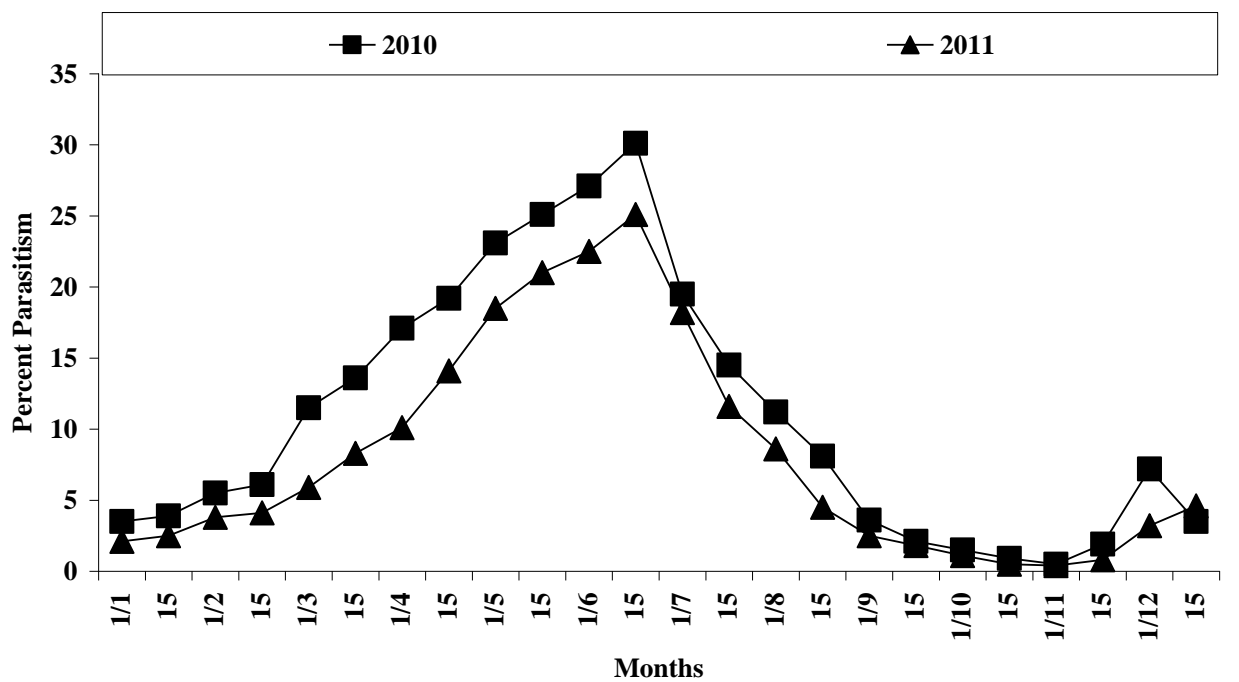

Fig. (5): Percent parasitism by Aphytis philippinensis associated with Chrysomphalus anonidum infesting Citrus sp. at Qalyubiya.

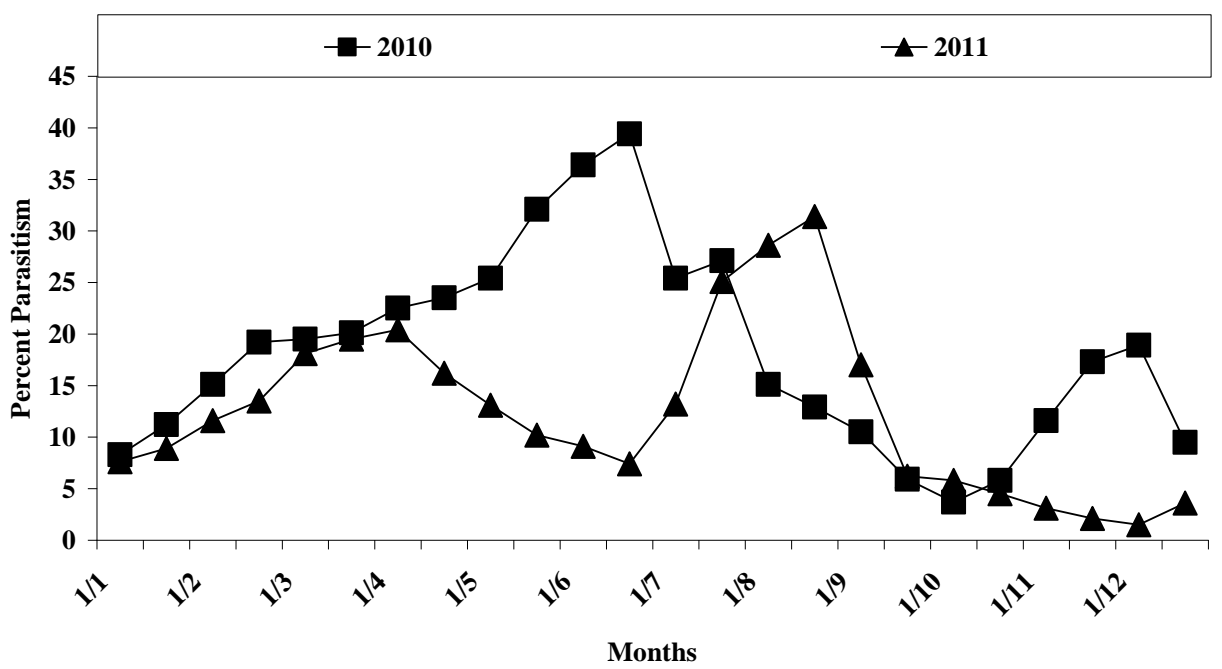

Fig. (6): Percent parasitism by Aphytis vandenboschi associated with Aspidiotus nerii infesting Oleander sp. at Behira. 


\section{REFERENCES}

1. Abd-Rabou, S. 1997a. Parasitoids attacking some species of scale insects (Homoptera: Coccoidea: Diaspididae) in Egypt.Proceeding of the First Scientific Conference of Agricultural Science, Cairo, Vol.II : 727-736.

2. Abd-Rabou, S. 1997b. Parasitoids attacking the olive scale insect, Parlatoria oleae(Colvee) (Homoptera:Coccoidea:Diaspididae) in Egypt.Proceeding of the First Scientific Conference of Agricultural Science,Vol.II:719-726.

3. Abd-Rabou, S. 2001. The effect of augmentative releases of indigenous parasitoids on populations of Parlatoria oleae (Colveé) (Hemiptera : Coccoidea) on Olive groves in Egypt. Boll.Zool.agr. Bachic.,SerII,33(3): 473-481.

4. Abd-Rabou, S. 2004. Revision of the genus Aphytis (Aphelinidae: Hymenoptera) with discriptions of two new species from Egypt. Entomologia Sinica, Vol.11(2):149-164.

5. Abd-Rabou, S. 2006. Hymenopterous parasitoids as a bioagent for controlling homopterous insects in Egypt. Egypt. Adv. Agric. Res. In Egypt, Vol. (6) 1: 1-65.

6. Abd-Rabou, S. and M. Hayat. 2003. A synopsis key to the Egyptian species of Aphytis Howard (Hymenoptera : Aphelinidae) parasitoids of diaspidid scale insects (Homoptera : Diaspididae). Acta Phytopathologica et Entomologica Hungerica, 38(3-4): 357-363.

7. Abd-Rabou, S. and A. S. Hendaway. 2000. Parastioids attacking date palm scale, Paralatoria balnchardi (Targ.) (Homoptera : Diaspididae) in Egypt. J. Agric. Sci. Mansoura Univ., 25 (12): 8217-8222.

8. Hafez, M. 1988. Population fluctuations on parasites of California red scale, Aonidiella aurantii (Mask) (Homoptera: Diaspididae) in Alexandria. J. App. Ent., 106 (2): 183-187.

9. Hafez, M., A. El-Minshawy and A. Donia. 1987. Population fluctuations of parasites of Lepidosaphes beckii Newm. and Ceroplastes floridensis Comst. Anz. Schadlingskde, Pflanzenschutz, Ummeltschutz, 60: 6-9.

10. Hayat, M. (1983): The genera of Aphelinidae of the world. Systematic Entomology, 8: 63-102.

11. Moursi, K. and H. Mesbah. 1985. Olive pests of irrigated farm systems in the Egyptian western desert with special references to armored scale insects. Annals of Agricultural Science, Moshtohor, 23 (2) 901-911.

12. Priesner, A. and M. Hosny. 1940. Notes on parasites and predators of Coccidae and Aleyrodidae in Egypt. Bull. Soc. Ent. Egypte, 24: 58-70.

13. Rosen, D (1988): Parasitic Hymenoptera in biological control: The genus Aphytis. In: Advances in Parasitic Hymenoptera Research (Ed V.K. Gupta), pp. 411- 416. E.J.Brill, Leiden.

14. Rosen, D. and P. De Bach. 1979. Species of Aphytis of the world (Hymenoptera : Aphelinidae). Boston-London, 779 pp. 
دور مجموعة البروكلايا من طفيليات جنس أفيتس كطفيليات مؤثرة

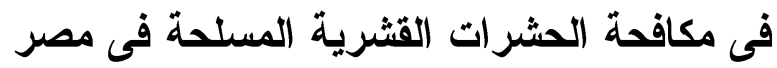

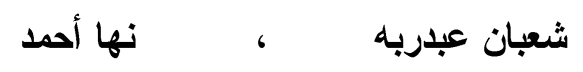$$
\text { معرة بحوث وقابة النباتات - مركز البحوث الزراعية - الدقى - جبزة - مصر }
$$

تعتبر مجموعة البروكلايا من طفيليات جنس أفيتس من أهم الطفيليات فى مكافحة الحشرات القشرية المسلحة فى مصر . هذا العمل يتضمن العائل الحشرى لهري

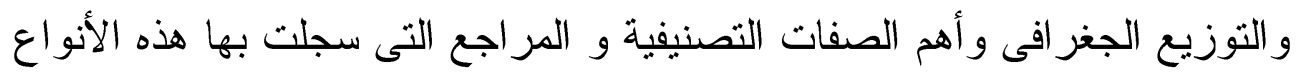
لأول مرة ومفتاح تصنيفى لهذه المجموعة ودور ها فى مكافحة الحشر ات القشرية 9 المسلحة. وقد أثار ات النتائج الى نسجيل 6 أنو اع من هذه الطفيليات تنطفل على

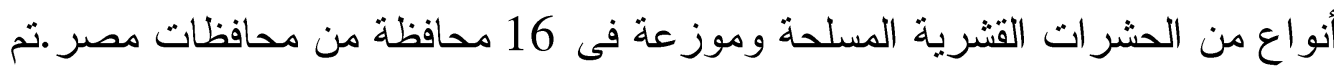
أيضا عمل مفتاح تصنيفى لهذه المجموعة من الطفيليات مع أضافة المر اجع العلمية

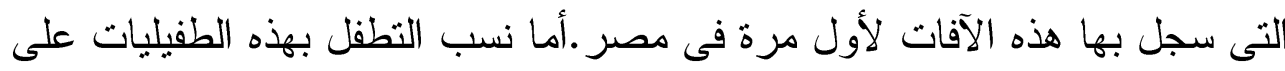

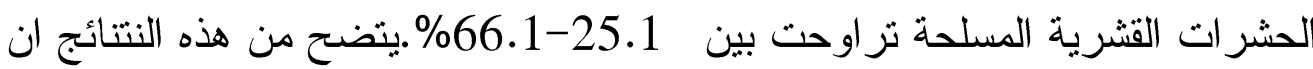
هذه المجموعة من طفيليات جنس أفينس لها دور فعال فى مكافحة الحشرات القشرية المسلحة فى مصر . لمجن. 